\section{Enhancement of Mouse-virulence of Group A Streptococci by Bactericidal Resorcinols}

IT seems to be generally agreed that agents capable of enhancing the virulence of bacteria, particularly mucins, do so by interfering with the defences of the host ${ }^{1-8}$. Recently, it was shown that broth or peptone injected intraperitoneally into $W$-Swiss mice even $1 \mathrm{hr}$. after a non-lethal saline suspension of group $A$ streptococci converts the non-lethal dose into an $L D 100$, the time-lag pointing again to an action on the host. The present communication brings further evidence in this respect; it also shows that substances bactericidal in vitro can act as virulenceenhancing agents in vivo.

The resorcinols were the 4-n substituted alkyl derivatives, ethyl, propyl, butyl, amyl and hexyl resorcinol ${ }^{5}$. The intraperitoneal injection of $0.5 \mathrm{ml}$. of a 0.1 per cent saline solution of these compounds is without marked effect on mice.

Two strains of group $A$ streptococci were used, one type 12, the other type 22; the $L D 100$ was $0.5 \mathrm{ml}$. of a $10^{-2}$ saline dilution of culture, the culture itself containing about $2 \times 10^{7}$ viable cells per ml. The organisms were grown in broth consisting of 2 per cent 'Oxoid' peptone, 0.8 per cent 'Oxoid Lab. Lemco' broth powder, 0.2 per cent glucose and 0.2 per cent sodium bicarbonate made up in distilled water, sterilized by Seitz filtration and tubed in 4-ml. lots in $t$ oz. screw-orpped Bijou bottles.

Two types of experiment were carried out. First, 18-hr. old cultures of streptococci were diluted 1 in 10 in 0.1 per cent solutions of the various resorcinols and kept, with occasional shaking, at room temperature, $24^{\circ}$, for $30 \mathrm{~min}$., a $10^{-1}$ saline-dilution of culture serving as control ; thereafter $W$-Swiss mice were injected intraperitoneally with $0.5 \mathrm{ml}$. of the suspensions from which viable counts were made all control animals and all animals injected with the ethyl and propyl resorcinol suspensions of organisms died. There were no deaths in the groups injected with the organisms exposed to butyl, amyl and hexyl resorcinol. The butyl, amyl and hexyl suspensions were found sterile whereas the ethy], propyl and saline suspensions still contained approximately the same number of viable organisms.

In the second group of experiments the organisms were not exposed in vitro to the action of the resor-

Table 1. EFFECT OF 4- $n$ ALKYL-SUBSTITUTKD RRSORCINOLS ON . MOUSE-VIROLENCE OF GROUP A STREPTOCOCOI

\begin{tabular}{|c|c|c|c|c|c|c|}
\hline \multirow[t]{2}{*}{ Strain } & \multirow[t]{2}{*}{ Alkyl resorcinol } & \multicolumn{5}{|c|}{$\begin{array}{c}\text { Deaths in groups of } 16 \text { mice } \\
\text { inoculated with the following } \\
\text { culture dilutions }\end{array}$} \\
\hline & & $10^{-2}$ & $10^{-8}$ & $10^{-4}$ & $10^{-5}$ & $10^{-8}$ \\
\hline $\begin{array}{l}\text { Cumming } \\
\text { Type 22 }\end{array}$ & $\begin{array}{l}\text { None-saline } \\
\text { control } \\
\text { Ethyl } \\
\text { Propyl } \\
\text { Butyl } \\
\text { Amyl } \\
\text { Hexyl }\end{array}$ & $\begin{array}{l}16 \\
= \\
-\end{array}$ & $\begin{array}{r}8 \\
8 \\
9 \\
- \\
\end{array}$ & $\begin{array}{r}0 \\
3 \\
5 \\
16 \\
16 \\
16 \\
\end{array}$ & $\begin{array}{r}0 \\
0 \\
0 \\
13 \\
16 \\
16 \\
\end{array}$ & $\begin{array}{r}0 \\
0 \\
0 \\
0 \\
11 \\
9 \\
\end{array}$ \\
\hline $\begin{array}{c}1965 \\
\text { Type } 12\end{array}$ & $\begin{array}{l}\text { None-saline } \\
\text { control } \\
\text { Ethyl } \\
\text { Propyl } \\
\text { Butyl } \\
\text { Amyl } \\
\text { Hexyl }\end{array}$ & $\begin{array}{l}16 \\
E \\
-\end{array}$ & $\begin{array}{r}10 \\
9 \\
13 \\
\\
\end{array}$ & $\begin{array}{r}1 \\
7 \\
5 \\
16 \\
16 \\
16\end{array}$ & $\begin{array}{r}0 \\
0 \\
0 \\
14 \\
16 \\
16\end{array}$ & $\begin{array}{r}0 \\
0 \\
0 \\
0 \\
11 \\
12\end{array}$ \\
\hline
\end{tabular}

- Mice injected intraperitoneally, first with $0.5 \mathrm{ml}$. of the stated saline dilutions of culture, then with $0.5 \mathrm{ml}$, of saline or of a $0.1 \mathrm{per}$ cent saline solution of an alkyl resorcinol. cinols : instead, mice were first injected intraperitoneally with $0.5 \mathrm{ml}$. of $10^{-2}-10^{-6}$ saline dilutions of culture and immediately afterwards with $0.5 \mathrm{ml}$. of a 0.1 per cent seline solution of the resorcinols; control animals were given intraperitoneally $0.5 \mathrm{ml}$. of the saline dilutions of culture followed by $0.5 \mathrm{ml}$. of saline. Under these conditions the resorcinols proved to be not disinfectants but virulence-enhancing agents and a 100 - to 1,000 -fold decrease of the $L D 100$ was observed (Table 1).

Thus it has been shown that the same substance can act both as a bactericide and as a virulenceenhancing agent, depending on the conditions of the experiment, and that in the alkyl resorcinols examined virulence-enhancing activity parallels bactericidal activity. The experiments rule out a true enhancement of virulence of the infecting organism and demonstrate that the action of the resorcinols is on the host.

\section{JoHN CAMERoN}

Clinical Chemotherapeutic Research Unit

of the Medical Research Council,

Western Infirmary,

$$
\text { Glasgow. }
$$

Dec. 20.

I Miller, C. P., and Castles, R., J. Inf. Dis., 58, 263 (1936),

Olitzki, L., Bact. Rev., 12, 149 (1948).

smith, H., J. Inf. Dis., 88, 207 (1951)

- Cameron, J Nature, 180, 1136 (1957).

${ }^{5}$ Frobisher, M., J. Bact., 13, 163 (1927)

- Miles, A. A., and Misra, S. S., J. Hyg. (Camb.), 38, 732 (1938).

\section{A Possible Source of Error in the Chemical Detection of Indolyl Acetic Acid in Plants}

DURING investigations on the growth substances of fruits of cacao and bananas (Musa spp.), it was of interest to find that a substance was present in seeded bananas which gave a pink colour with ferric chloride/perchloric acid or $p$-dimethyl amino-benzaldehyde/hydrochloric acid, corresponding to the $R_{F}$ of indolyl acetic acid and to the zone of biosssay using the wheat coleoptile straight-growth test. Subsequent experimentation showed that although the straight-growth response was probably due:to indolyl acetic acid, the colour reaction was not. The technique of extraction and bioassay was essentially similar to that of Bennet-Clark and Kefford ${ }^{1}$ with some minor modifications. Duplicate samples of the acid fraction from seeded banana fruit extracts were developed by the descending method on Whatman's $3 M M$ or No. 1 chromatography paper in isopropanol/ ammonia/water $(10: 1: 1)$. Synthetic indolyl acetic acid was developed as a marker. One sample was bio-assayed by the wheat straight-growth test and the other sprayed with ferric chloride/perchloric acid ( $1 \mathrm{ml}$. $0.05 M$ ferric chloride $+50 \mathrm{ml}$. 5 per cent perchloric acid).

The ferric chloride/perchloric acid spray, on heating, developed a pink or pinkish-purple spot on the chromatogram corresponding to both the zone of growth activity after bio-assay and to the indolyl acetic acid marker. The top half of the chromatogram $\left(R_{F}<0.5\right)$ was usually streaked with oxidized polyphenolic substances which could be detected visually without treatment by the brown colour and confirmed by diazotized $p$-nitraniline. It was found that if synthetic indolyl acetic acid was spotted into 